\title{
USO DE COLOSTRO FERMENTADO NATURALMENTE E PRESERVADO COM FORMALDEIDO NO ALEITAMENTO DE BEZERROS
}

\section{GBEDJANGNI KODJO}

Orientador: Prof. Dr Max Lázaro Vieira Bose

Dissertaçào apresentada à Escola Superior de Agricultura "Luiz de Queiroz", da Universidade de São Paulo, para obtençào do Titulo de Mestre em Nutriçào Animai e Pastagens

PIRACICABA

Estado de São Paulo - Brasil

Novembro, 1980 
DEDICO:

A os meus pais

GBEDIANGNI e DJOSSIVI

Aos meus irmãos

AFANOU, AFANOUKOE, AKOUETE $~ E$ EDOH

Ao meu tio

A FATSAO 


\section{AGRADECIMENTOS}

Ao Prof. Dr. Max Lázaro Vieira Bose, pela orientação, apoio e amizade dedicados durante o desenvolvimento deste trabalho;

Ao Prof. Dr. Irineu Umberto Packer, pela valiosa colaboração na análise estatística dos dados;

Ao Prof. Dr. Abel Lavorenti, pela Coordenação do Curso de Pós-Graduação em Nutrição Animal e Pastagens;

Aos Profs. Drs. Vidal P. Faria, Wilson R. Soares Mattos e Celso Lemaire de Moraes, pela colaboração e sugestões durante o Curso;

Ao Eng Renato Rappa, por ter colocado à disposiçã̃ a Fazenda "Atí bainha", com pessoal, instalações, animais e material de consumo necessários para a condução da parte experimental deste trabalho;

A Coordenadoria de Atividades Culturais da Universidade de São Paulo, pela concessão de bolsa de estudo;

A Fundação Cargill, pela colaboração para o procedimento deste trabalho;

Aos Colegas do Curso de Nutrição Animal e Pastagens, pelo apoio e amizade dedicados durante a realização deste trabalho;

Ass Secretárias dos Departamentos de Zootecnia e de Matemática e Es tatistica, Sónia Maria Delfine e Maria Izalina Ferreira Alves. 
Pāg.

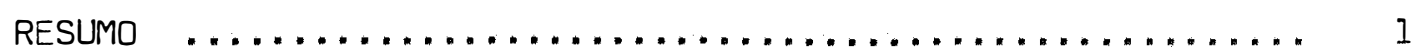

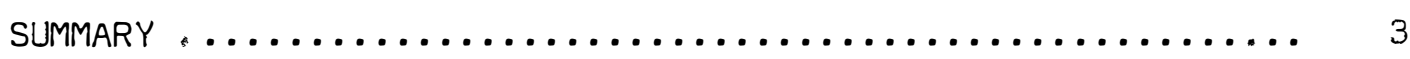

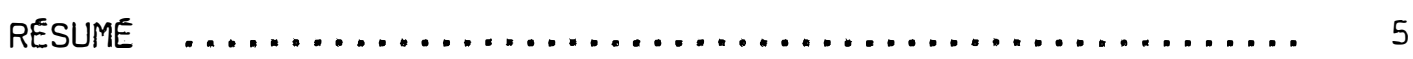

1. INTRODUÇÃO $\ldots \ldots \ldots \ldots \ldots \ldots \ldots \ldots \ldots \ldots \ldots \ldots \ldots \ldots \ldots \ldots \ldots \ldots$

2. REVISÃo de LITERATURA. .........................

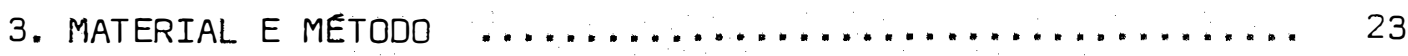

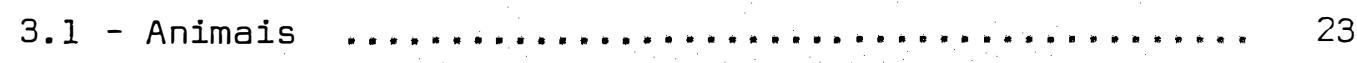

3.2 - Manejo de Arraçoamento ..................... 24

3.3 - Preparo do Colostro Fermentado ............... 28

3.4 - Preparo do Colostro Preservado com Formaldeído .... 29

3.5 - Preparo do Sucedâneo $\ldots \ldots \ldots \ldots \ldots \ldots \ldots \ldots \ldots \ldots \ldots . \ldots \ldots$

3.6 - Delineamento Experimental ............... 30

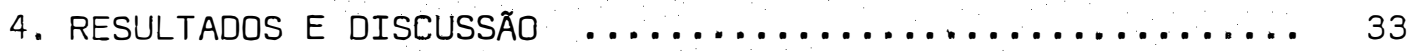

4.1 - Aceitabilidade e Problemas Sanitários .......... 33

4.2 - Consumo de Leite em Pó, Colostro Fermentado e Colos-

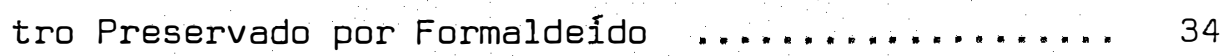

4.3 - Consumo de Ração Inicial $\ldots \ldots \ldots \ldots \ldots \ldots \ldots \ldots . \ldots . \ldots . \ldots$

4.4 - Consumo Total de Alimento $\ldots \ldots \ldots \ldots \ldots \ldots \ldots \ldots . \ldots . \ldots 4$

4.5 - Ganho de Peso $\ldots \ldots \ldots \ldots \ldots \ldots \ldots \ldots \ldots \ldots \ldots \ldots . \ldots \ldots$

4.6 - Conversão Alimentar ...................... 54

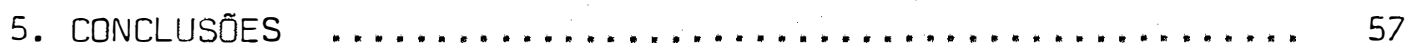

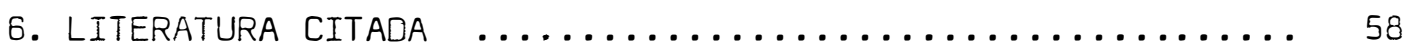

7. APENDICE $\ldots \ldots \ldots \ldots \ldots \ldots \ldots \ldots \ldots \ldots \ldots \ldots \ldots \ldots \ldots \ldots \ldots \ldots \ldots \ldots \ldots \ldots$ 
RESUMO

Com o objetivo de averiguar sobre a viabilidade de utilização de colostro fermentado naturalmente e colostro preservado com formaldeído em aleitamento de bezerros, através de consumode alimento, desenvolvimento ponderal, conversão alimentar e estado sa nitário, trinta bezerros de ambos os sexos, da raça Holandesa malha da de preto, foram submetidos a três sistemas de aleitamento na fa-. se de 1 a 35 dias de idade: $1^{8}$ ) sucedâneo de leite; $2^{8}$ ) colostro fer mentado e $\left.3^{\circ}\right)$ colostro preservado com formaldeído. As dietas líquidas foram suplementadas à vontade com ração inicial de $18 \%$ de proteina bruta e feno de Kikuiu (Pennisetum clandestinum Hochst), de $19,8 \%$ de proteína bruta. Os animais foram distribuídos nos referidos tratamentos conforme delineamento de "experimentos inteiramente casualizados". 
Os consumos médios diários, ganhos médios diārios de peso e conversão alimentar até os animais completarem 35 dias de idade foram, para os respectivos tratamentos, de $0,820 \mathrm{~kg}, 0,281 \mathrm{~kg}$ e 3,27; 0,796 kg, 0,396 kg e 2,23;0,750 kg, 0,284 kg e 3,13. Da desmama até à 26: semana, os ganhos diärios médios foram de 0,655, 0,605 e $0,533 \mathrm{~kg}$.

Em relação a problemas sanitários, observou-se que 4 bezerros dos 10 alimentados com sucedâneo apresentaram diarréia,con tra 2 em cada grupo de animais sob regime de colostro.

Os resultados indicaram que colostro fermentado e o preservado por formaldeído são excelentes alimentos substitutivos do leite integral ou de sucedâneo de leite. Apesar de não ter havido diferença significativa entre ambos os sistemas de aproveitamento, - colostro fermentado parece levar vantagem sobre o preservado por formaldeído pela sua mais fäcil preparação e melhor utilização pelo animal. 
SUMMARY

Thirty Holstein calves were used to inquire viability of utilization of naturally fermented or formaldehyde preserved colostrum through intake; growth, feed conversion and scouring incidence. Calves were alloted in á completely random design at 4 days of age to $1^{8}$ ] milk replacer diet, $2^{8}$ ) naturally fermented colostrum, $\left.3^{\circ}\right)$ formaldehyde preserved colostrum. All calves were offered add libitum, 18\% crude protein calf stater and Pennisetum clandestinum hay $(19,8 \%$ protein).

Average daily intake, gain and feed conversion at weaning ( 35 days of age) for treatments 1,2 and 3 were respectively $0.820 \mathrm{~kg}, 0.281 \mathrm{~kg}, 3.27 ; 0.796 \mathrm{~kg}, 0.396 \mathrm{~kg}, 2.23 ; 0.750 \mathrm{~kg}, 0.284$ $\mathrm{kg}$ and 3.13. From weaning to 26 weeks of age, average daily gains we- 
re $0.655,0.605$ and $0.533 \mathrm{~kg}$. Four calves scouring (diharrea) on milk replacer diet and two on each colostrum diet.

Resultats indicated that both, naturally fermented and formaldehyde preserved colostrum are excellents substitutes feeds for whole milk or milk replacer. In spite of no existing significative diffence between both colostrum feeding systems, naturally fermented colostrum seems to be more advantageous than formaldehyde pre served colostrum by presenting easy prepartion and best utilization. 
RESUME

Pour determiner la viabilité de l'utilisation du colostrum fermenté naturellement ou preservé avec du formaldeide dans l'allaitement de veaux à travers de l'ingestion, développement pondéral, conversion alimentaire et état sanitaire on a utilisé trente veaux de la race Holstein dans un essai entièrement an hasard. Les veaux ont été soumis aux suivants traitements: 1) lait reconstitué, $2^{\circ}$ colostrum fermenté naturellement, $\left.3^{\circ}\right)^{\prime}$ colostrum préservé avec du formaldeide. Em plus des diètes "lacteés", les animaux ont recu à libre choix, une ration concentrée de demarrage de $18 \%$ de proteine brute et un foin de Pennisetron clandestinum. Hochst de 19,8\% de pro teine brute.

La consommation journaliére, le gain moyen journalier et la conversion alimentaire au sevrage à trente - cinq jours d'àge 
pour les respectifs treatements ont été les suivants: $0,820 \mathrm{~kg}, 0,281$ $\mathrm{kg}, 3,27 ; 0,796 \mathrm{~kg}, 0,396 \mathrm{~kg}, 2,23 ; 0,750 \mathrm{~kg}, 0,284 \mathrm{~kg}, 3,13$. Du sevrage à vingt-six semaines d'âge, les gains moyens quotidiens ont été $0,655,0,605$ et $0,533 \mathrm{~kg}$. En ce qui concerne l'état sanitaire, quatre veaux sur les dix alimentés avec le lait reconstitué on eu de la diarrhée et aussi deux veaux dans chacun des groupes alimentés avec des diètes à base de colostrum.

Les resultats indiquent que le colostrum fermenté ou preservé avec du formaldeide constituit un excellent aliment de substitution du lait entier ou reconstitué; et malgré qu'il n'existe une diférence significative entre les deux sistèmes d'alimentation, le colostrum fermenté semble être plus avantageux que le colostrum preservé avec du formaldeide pour avoir présenté un sistème de preparation facile et une meilleure utilisation par le veau. 


\section{INTRODUÇÃO}

Geralmente, o colostro, as primeiras secreções das glândulas mamárias logo após parto, não tem preço para fim comercial, e, na realidade, as produções são superiores às necessidades do recém-nascido, que precisa tomar o colostro nas suas primeiras ho ras de vida. O excesso pode ser aproveitado na fase de aleitamento, para minimizar o custo de criação do bezerro. o colostro, conservado em adequadas condições higiēnicas, constitui um eficiente alimen to de alto valor nutritivo para substituir o leite integral ou suce dâneo de leite comumente utilizado. Talvez o uso da sobra de colostro resolveria grande parte das dificultadas econōmicas encontradas na criação do bezerro macho em rebanhos leiteiros. E importante a quantidade de colostro que sobra nas fazendas de gado de leite e que é, na maioria dos casos, mal aproveitado por falta de condições de conservação. 
Tem-se devensolvido vários trabalhos com a finalidade de revalorizar o aproveitamento da sobra de colostro através de diferentes processos de armazenamento, sejam pelo frio, pela fermen tação á temperatura ambiente, ou por meio de produtos químicos. A conservação pelo frio pressupõe a disponibilidade de espaço suficiente no refrigerador ou na câmara frigorífica para este fim, o que nem sempre está ao alcance do criador médio em nossas condições de exploração leiteira. Os processos de armazenamento mais fáceis e ba ratos são a fermentação à temperatura ambiente, ou uso de aditivos ou produtos químicos. Embora exista problema quanto à aceitação pelo bezerro na fase inicial, o colostro fermentado ou tratado com aditivos tem proporcionado taxa normal de crescimento de bezerros quando comparado ao uso de leite integral ou a sucedâneo de leite.

o presente trabalho tem como objetivo averiguar sobre a viabilidade de utilização de colostro fermentado naturalmente, e de colostro preservado com formaldeído em aleitamento de bezerros, através de observações e determinações relativas a:
a) consumo de alimento;
b) conversão alimentar;
c) desenvolvimento ponderal até 6 meses de idade;
d) estado sanitário. 


\section{REVISÃO DE LITERATURA}

A importância do colostro para o recém-nascido é assunto bastante explorado. O colostro secretado pela vaca parida con tém alta quantidade de gama-globulina, necessária para dar imunidade à cria. Ehrlich (1892), citado por JACOBSON (1951), relatou que, além de conter gama-globulina, o colostro constitui principal fonte de proteína, lipídeo, minerais e vitaminas para o recém-nascido. Em relação aos minerais, Garret e Overman (1940), citados por JACOBSON (1951), afirmaram que o colostro é fonte essencial de cálcio, magnê sio, sódio, fósforo e cloro para a cria.

\section{1 - Colostro Como Al imento Substituto do Leite}

O valor potencial do colostro como substituto do lei te integral no aleitamento de bezerro, reside na sua fácil disponi- 
bilidade na fazenda, na impossibilidade de comercialização, na riqueza em nutrientes essenciais, e no fácil armazenamento para uso futuro (FOLEY e OTTERBY, 1978).

Tentativas de uso da sobra de colostro no aleitamento de bezerro referem-se aos anos de 1950. ALLEN (1944) utilizava so bra de colostro como alimento substituto do leite, e afirmou que era o único caminho de aproveitamento desse produto tão eficiente e barato para a criação do bezerro. Mais tarde, KAESER et alii (1948) relataram que o uso do colostro como alimento de bezerro tem duas vantagens, isto é, além de ser um alimento benéfico para a saúde do animal, é um produto não comerciável e permite minimizar os custos do bezerro.

\section{2 - Aceitabilidade da Dieta de Colostro}

Num levantamento sobre uso de colostro como alimento barato e de alto valor nutritivo, FOLEY et alii (1978) concluiram que geralmente o colostro fresco ou conservado é aceito espontaneamente pelo bezerro sem nenhuma dificuldade. Em relação ao colostro fermentado, existe problema de aceitabilidade na fase inicial, devi do a mudança brusca no sabor, odor e pH do alimento. Eles afirmaram ainda, que o maior índice de rejeição do colostro fermentado ocorreu durante as estações quentes do ano, devido ao forte odor de áci do acético produzido durante o processo fermentativo. A queda de aceitabilidade está diretamente ligada ao aumento da acidez do produto.' 
RINOSIG e BODOH (1975), trabalhando com bezerros holandeses de 3 a 35 dias de idade, relataram ter encontrado maior in dice de sobra de dietas líquidas em bezerros alimentädos com colostro tratado com ácido propiōnico do que em relação ao preservado com formaldeido, ou com o fermentado à temperatura ambiente. 0 problema foi relacionado com o mau odor e pH muito baixo.

Na avaliação de dietas líquidas para bezerros recém-nascidos, MULLER et alii (1976) tiveram maior problema para conseguir que o bezerro ingerisse quantidade suficiente de colostro fermentado ou tratado com ácido propiônico também durante a estação quente do ano. Os autores passaram a recomendar a adição dos ácidos preservativos ao colostro, logo após a ordenha para evitar início de processo fermentativo, resultando em um produto mal conservado. POL ZIN et alii (1975), ao contrário, trabalhando em período quente, não encontraram nenhum problema quanto à aceitabilidade do colostro fer mentado ou tratado com ácido propiônico, enquanto KAIZER (1976) men cionou possível deterioração e odor inaceitável pelo bezerro quando o colostro foi tratado com formaldeido.

OTTERBY et alii (1976), empregando sucedāneo de leite e colostro fermentado, constataram rejeição quase total das duas primeiras refeições, mas a aceitação desse alimento melhorou logo a seguir. Eles consideraram esta fase inicial de rejeição como um período de adaptação ao novo regime de aleitamento. Em trabalho semelhante, JENNY et alii (1977) relataram ter sido necessário insistir 
para fazer o bezerro consumir colostro fermentado nos seis primeiros dias de experimento.

\section{3 - Desempenho dos Bezerros}

o colostro, devido ao seu elevado conteúdo em sólidos totais, deve ser diluído para aproximar-se da concentração normal do leite integral. Na prática, o diluente mais usado é a água (FOLEY et alii, 1978). As proporções de diluição (partes colostro : : parte águal frequentemente utilizadas são: $1: 1,2: 1$ e $3: 1$.

JENNY et alii (1977) estudaram efeito de três diluições - 1:1, 2:1 e 3:1 (colostro fermentado : água) - sobre desempenho de bezerros holandeses na fase de 3 a 30 dias de idade. As die tas líquidas foram oferecidas na base de $10 \%$ de peso vivo em duas refeições diárias, mais ração inicial à vontade. Os bezerros alimen tados com leite integral, colostro diluído a 2:1 e 3:1 apresentaram ganhos diários de peso semelhantes $(0,46-0,43-0,46 \mathrm{~kg})$, enquanto que a diluição l:l prejudicou o crescimento, proporcionando ganho diário de peso de 0,35 kg. Após a desmada, ao atingirem 45 dias de vida, todos os bezerros apresentaram mesma taxa de ganho de peso diário, mostrando que não houve efeito do tipo de dieta recebida na fase anterior $(0,43 ; 0,40 ; 0,43 ; 0,45 \mathrm{~kg})$.

Avaliando a melhor forma de diluição do colostro fer mentado para aleitamento de bezerros machos leiteiros holandeses, RINOSIG (1975) trabalhou com colostro diluído com água morna nas pro 
porções de $1: 1,2: 1$ e 3:1. No experimento, dividido em dois ensaios, foram oferecidos respectivamente, a dois grupos de bezerros: ( ${ }^{8}$ ) 1,84 kg de colostro fermentado diluído em 1,84 kg dé água morna $(1: 1)$ e (28) $2,7 \mathrm{~kg}$ de colostro fermentado diluído em $0,90 \mathrm{~kg}$ de água morna (3:1). Num segundo ensaio, o consumo foi ajustado a $10 \%$ do peso vivo e o colostro diluído na proporção de 2:1. A diluição 3:l levou a maior ganho diário de peso do que $1: 1(0,25$ e 0,18 kg). 0 consumo de colostro ajustado a 10\% do peso vivo e diluído a $2: 1$ proporcinou maior ganho diário de peso $(0,32 \mathrm{~kg})$.

A fim de determinar as proporções de diluição de colostro para não prejudicar o crescimento do bezerro, MULLER et alii (1975) ofereceram, respectivamente, a 3 grupos de animais, 3,64 kg de leite integral diário, 1,84 kg de colostro fermentado + 1,84 kg de água, $2,73 \mathrm{~kg}$ de colostro $+0,91 \mathrm{~kg}$ de água morna, isto é, numa diluição de l:l e 3:1. Observou-se rápido desenvolvimento dos animais alimentados com o leite integral ou colostro diluido a $3: 1$, sendo o ganho diário médio de peso de $0,280 \mathrm{~kg}$ e 0,240 kg ao comple tar 35 dias de vida. Quanto ao colostro diluído a l:l, resultou em crescimento vagoroso, com ganho diário médio de peso de apenas 0,09 kg, devido a ingestão insuficiente de nutrientes.

WHITE et alii (1974), trabalhando com colostro fermentado à temperatura ambiente, diluído a $l: l$, e sucedâneo de leite comercial, verificaram melhor desempenho de bezerros holandeses machos sob dieta de colostro fermentado, sendo de $10,21 \mathrm{~kg}$ e $5,17 \mathrm{~kg}$ os ganhos respectivos de pesos acumulados de 1 a 40 dias de idade. 
Procurando avaliar a melhor forma de conservação da sobra de colostro, MORRILL et alii (1974) trabalharam com colostro preservado por resfriamento ou por fermentação natural diluído a 3:1, no aleitamento de bezerros holandeses, sendo a dieta líquida oferecida em uma refeição diária, e ração inicial à vontade. Os pes quisadores concluiram não haver diferenças significativas a respeito de ocorrência de diarréias, devido ao sistema de conservação, e verificaram que os animais alimentados com colostro fermentado tive ram 14,8 kg de ganho de peso e 11,2 kg de consumo de ração inicial contra $13,8 \mathrm{~kg}$ e $8,2 \mathrm{~kg}$ para o colostro congelado.

Segundo VAN et alii (1975), a diluição do colostro fermentado na proporção de 2:1 (colostro : água) é mais eficiente que $1: 1$, pois na diluição por partes iguais o bezerro estaria ingerindo insuficiente quantidade de matéria seca, e consequentemente teria crescimento vagaroso, podendo até chegar à morte. Entretanto, após a desmama ocorre uma recuperação rápida dos animais em regime de colostro diluído a $l: 1$, e o rítmo de crescimento é semelhante ao dos animais criados na dieta diluída a $2: 1$.

Na avaliação do efeito do tipo de dieta líquida sobre ganho de peso e conversão alimentar de bovino jovem, OANIELS et alii (1975) ofereceram a bezerros holandeses de 3 dias de idade, na base de $10 \%$ de peso vivo, sucedâneo de leite, colostro natural fermentado, colostro inoculado por bactérias lácticas e colostro preservado por adição de ácido acético, e, conjuntamente, uma ração i- 
nicial de 18\% de proteína bruta, à vontade. Os animais apresentaram ganho diário de peso de 0,24, 0,29, 0,20 e 0,32 kg, nas respectivas dietas líquidas; o consumo diário de matéria seca foi de 0,25, 0,53, 0,42 e 0,51 kg; a conversão alimentar foi de 3,22, 2,59, 3,15 e 2,37. Conclui-se que o colostro fermentado ou preservado por acidificação constitui um excelente alimento de substituição para o suce dôneo de leite.

OTTERBY et alii (1976) utilizaram leite comercial em pó e colostro fermentado para bezerros holandeses, no período de 4 a 28 dias de vida, sendo o leite comercial oferecido à base de 0,32 kg de matéria seca diária e 2,27 kg de colostro. O critério da desmama foi: 28 dias de idade ou consumo mínimo de $0,45 \mathrm{~kg}$ de ração inicial com 17\% de proteína bruta. Os melhores resultados foram obti dos com os bezerros alimentados com o colostro fermentado, sendo o ganho de peso total de 6,3 kg contra $2,8 \mathrm{~kg}$ para os animais criados em dieta de leite comercial. Entretanto, levando em consideração o desenvolvimento dós bezerros 12 semanas após a desmama, não houve diferenças significativas entre os dois sistemas de aleitamento.

Em trabalho em que se usou crescimento de bezerros como parâmetro de avaliação de colostro natural fermentado ou preservado com ácido propiōnico, ou folmaldeido, MULLER et alii (1976) reportaram que o leite integral resultou em melhor ganho diário de peso $(0,250 \mathrm{~kg})$ do que colostro fermentado à temperatura ambiente $(0,150 \mathrm{~kg})$, colostro tratado com ácido propiónico $(0,210 \mathrm{~kg})$ ou colostro tratado com formaldeido $(0,180 \mathrm{~kg})$. Os autores concluiram que 
ambos ácidos - propiônico e formaldeido - são excelentes aditivos para a preservação do colostro.

RINSING e BODOH (1977), utilizando bëzerros holande ses de três dias de idade, avaliaram o desempenho deles até completarem 35 dias de vida, fornecendo-lhes leite integral, colostro fer mentado à temperatura ambiente, colostro preservado com ácido propiônico ou formaldeído. O consumo foi ajustado a $9 \%$ do peso vivo, e - colostro diluído na proporção de duas partes para uma de água mor na. Os bezerros apresentaram mesmo ritmo de crescimento, sendo os ganhos diários de peso de 0,30, 0,30, 0,27 e 0,28 kg, respectivamen te. Ọ consumo diário de matéria seca foi de $0,61,0,56,0,48$ e 0,56 kg. Entretanto, o colostro fermentado à temperatura ambiente e o pre servado com ácido propiōnico resultarám em maior índice de sobra pe lo animal, principalmente nos períodos quentes, com temperatura ambiente superior a $24^{\circ} \mathrm{C}$.

A respeito da idade ideal para substituir o leite in tegral por colostro fermentado na fase de 1 a 21 dias de vida, GONZALES et alii (1978) forneceram a diferentes grupos de bezerros holandeses e Friesan colostro fresco até o $7^{\circ}$ dia, colostro fermentado até o $7{ }^{\circ}$ dia, só colostro fermentado do $1^{\circ}$ ao $21^{\circ}$ dia, e a um ú timo grupo ofereceram quantidades iguais de colostro fermentado e de leite integral em refeições separadas. No final dos 21 dias, só os bezerros que receberam colostro fresco do nascimento ao $7^{\circ}$ dia apre sentaram ganho diário de peso significativamente superior aos demais 
$(0,524 ; 0,433 ; 0,471$ e 0,405 kg). Até os 40 primeiros dias de vida, os bezerros criados em regime exclusivo de colostro fermentado tive ram o melhor desempenho, sem qualquer problema espećial de saúde, le vando à conclusão de que o colostro fermentado pode substituir satisfatoriamente o leite integral, promovendo apreciável redução no custo de criação dessa categoria de animais.

WINTER (1978) estudou o efeito do uso de colostro fer mentado, sendo a idade de desmama estabelecida de $2,3,4$ e 5 semanas de vida. Não foi encontrada diferença significativa tanto quanto a ganho de peso total $(34,4 ; 30,8 ; 30,4$ e $35,3 \mathrm{~kg})$, quanto a con sumo de alimento até os bezerros atingirem a 12 ? semana de vida. En tretanto, devido a complicações sanitárias, e perda de alguns dos bezerros desmamados antes ou aos 21 dias, o autor recomendou corte da dieta líquida somente mais tarde, caso ocorresse diarréia antes do animal completar 3 semanas.

Trabalhando com bezerros de várias raças, Holandesa, Jersey, Guernsey e mestiços Guernsey x Arshire, para avaliar o efei to do uso de colostro fermentado ou tratado com os ácidos propiónico, acético ou fórmico, como substituto do leite integral, POLZIN et alii (1977) afirmaram que a conservação do colostro por meio da fermentação à temperatura ambiente resultou em maior perda, de nutrientes e, consequentemente, menor ganho diário de peso $(0,186 \mathrm{~kg})$ dos animais na desmama, quando comparado à conservação por acidificação imediata após coleta $(0,241$ kg), embora ao decorrer de 180 
dias de vida os animais, em todos os tratamentos, apresentarem ganhos de peso diários similares $(0,572 ; 0,531$ e 0,571 kg), indicando que o tipo de dieta líquida recebida no período de aleitamento não afetou o crescimento normal.

Segundo KAISER (1976), o colostro preservado por adi ção de formalina não tem se mostrado tão eficiente no desenvolvimen to dos bezerros quando comparado ao aleitamento com leite integral, mas contribui para uma redução substancial no custo de criação. KAI SER concluiu recomendando a utilização da formalina na preservação do colostro para aleitamento de bezerros nas fazendas de gado de leite.

FOLEY e OTTERBY (1979), em dois ensaios, compararam o desempenho de bezerros holandeses, em regime de colostro fermenta do à temperatura ambiente e conservado pelo frio ou pela adição de ácido lático. Observaram na desmama, aos 28 dias de vida, mínimos casos de rejeição das dietas, e os animais tiveram excelente aparên cia física. Em relação aos outros parâmetros, afirmaram não ter encontrado diferenças significativas quanto a consumo de ração inicial, de proteína bruta e conversão alimentar, enquanto que o ganho diário de peso apresentou ligeira vantagem com o colostro fermentado $(0,230 \mathrm{~kg})$ quando comparado com os bezerros criados com colostro conservado pelo frio ou pela adição de ácido lático $(0,18-0,20$ kg) . Afirmaram não ter ocorrido nenhum problema após a desmama, e todos os animais tiveram ganhos de pesos semelhantes. 
POLZIN et alii (1974), em experimento em que usaram parâmetros de desempenho de bezerros para avaliação de alimentos,me diram ganho de peso e consumo, fornecendo sucedâneo de leite e colostro fermentado. Não houve diferença significativa entre os tratä mentos. Contudo, o consumo e o ganho de peso dos animais no regime de colostro fermentado foram ligeiramente superiores aos do sucedâneo de leite. Segundo WINTER (1976), utilizando a mesma metodologia, não existe diferença significativa quanto ao consumo e ganho de peso quando bezerros são alimentados com colostro fermentado ou leite integral e uma ração inicial de $20 \%$ de proteína bruta.

A fim de determinar o valor nutritivo de sucedôneo de leite, colostro fermentado e leite integral, CHIK et alii (1975), utilizando bezerros de 3 dias de idade, constataram os seguintes va lores de consumo total de matéria seca, ganho de peso total e conversão alimentar: $29,07 \mathrm{~kg}-14,18 \mathrm{~kg}-2,05 ; 26,74 \mathrm{~kg}-16,87 \mathrm{~kg}-$ - 1,58; e 26,67 kg - 16,12 kg - 1,65, para os respectivos tratamentos, mostrando que o colostro fermentado apresentou melhor índice de conversão alimentar em relação ao sucedâneo de leite.

A substituição parcial ou inteira do leite integral por colostro fermentado não proporciona diferença significativa na criação de bezerros recém-nascidos, concluiu POLZIN et alii (1975), trabalhando com 52 bezerros holandeses, fornecendo 2,73 a 3,64 kg de colostro fermentado diluído, em uma refeição diária, no período do I: ao 26: dia de idade. 
YUYU et alii (1976) compararam efeito de leite integral e colostro fermentado à temperatura ambiente, sobre desempenho de bezerros do $7^{8}$ ao $35^{\circ}$ dia de vida. Não houve diferença na taxa de crescimento de animais. Portanto, a ingestão da ração inicial(de 20\% de proteína bruta) foi maior no grupo de bezerros que recebeu colostro fermentado do que no que recebeu leite integral $(13,3 \mathrm{~kg}$ vs $10,6 \mathrm{~kg} / 35$ dias). O uso de colostro reduziu em $90 \%$ o custo da criação dos bezerros leiteiros.

Colostro fermentado pode prejudicar ganho de peso dos bezerros quando comparado ao sistema normal de alimentação com leite integral, conforme PLOG et alii (1974), que trabalharam com bezerros holandeses, estudando o valor nutritivo de colostro fermenta do ou preservado pelo frio. Entretanto, não encontraram nenhuma relação entre tipo de dieta e teor de gama-globulina no sangue dos animais criados nos referentes sistemas de aleitamento.

\section{4 - Problemas Sanitärios}

Em relação a ocorrências eventuais de distúrbios digestivos, principalmente diarréia, KAISER (1976) e OTTERBY et alii (1976) afirmaram não ter encontrado diferenças quando os bezerros foram alimentados com leite integral ou com colostro fermentado. Eon tudo, MULLER et alii (1975) reportaram maior ocorrência de diarréia sob regime de leite integral.

WHITE et alii (1974), trabalhando com colostro fer- 
mentado e sucedāneo de leite comercial, relataram ter encontrado maior indice de ocorrência de diarréia nos bezerros criados sob regime de sucedâneo de leite. DANIELS et alii (1977), óferecendo colostro fermentado, tratado com ácido ou inoculado, e sucedâneo aos bezerros na fase dos 3 aos 45 dias de vida, constataram maior ocorrência de distúrbios digestivos em animais alimentados com o sucedâ neo do que no sistema de aleitamento baseado em colostro. Eles con cluiram que a alta digestibilidade do colostro seria a possível explicação para a menor incidência de diarréia em relação ao sucedāneo.

Avaliando a resposta de bezerros ao aleitamento com colostro fermentado ou preservado por adição dos ácidos propiónico, acético ou fórmico, POLZIN et alii (1977) não encontraram problemas de diarréias relacionados com o tipo de dieta recebida. Os animais tiveram excelente aparência física, sem nenhum caso de mortalidade, e apenas algumas horas de diarréia por bezerro. RINDSIG e BODOH (1977), utilizando a mesma metodologia, afirmaram não haver diferen ças significantes quanto à frequência de distúrbios digestivos em bezerros alimentados com colostro fermentado ou preservado por ácido propiōnico ou formaldeido.

MULLER et alii (1976), trabalhando com bezerros holandeses recém-nascidos, revelaram maior persistência em diarréia nos animais criados em dieta de colostro tratado com formaldeido do que em dieta de leite integral ou de colostro fermentado. 
Em relação ao efeito da diluição do colostro sobre distúrbios digestivos, JENNY et alii (1977) reportaram um máximo de 2,67 dias de diarréia por bezerro, sob regime de colostro diluído a $1: 1,2: 1$ e $3: 1$ (parte colostro : parte água morna). 
23.

\section{MATERIAL E METODOS}

o presente trabalho foi conduzido durante o período de 28/07/79 a 28/06/80, na "Fazenda Atibaínha", localizada no Município de Itatiba, Estado de São Paulo. Trata-se de uma das principais propriedades dedicadas à exploração de gado leiteiro da raça holandesa no Estado de São Paulo.

A fazenda proporcionou instalações, animais, colostro, ração, feno, balança e tratador de bezerros.

\section{1 - Animais}

Foram utilizados 30 animais, desde o nascimento até completarem 180 dias de idade, lançando-se mão de animais-reserva quando necessário. Os pesos vivos iniciais variaram de 30,20 a 68,5 kg. Ao nascer, os animais permaneceram 24 horas com a mãe, para re- 
ceber colostro em condições naturais. No segundo dia, eram transferidos a baias individuais, e aí recebendo colostro fresco até o $3^{8}$ dia. Cada baia era identificada com plaqueta contendó número de bezerro e o tratamento recebido. Foram utilizados unicamente animais oriundos de partos normais, assegurando-se cria normal, com mais vi talidade. Os 30 animais empregados foram de ambos os sexos, sendo 15 de cada.

\section{2 - Manejo de Arraçoamento}

No primeiro dia, os bezerros receberam o colostro in natura. No $2^{\circ}$ e $3^{\circ}$ dias, o colostro foi oferecido em balde. A partir do 48 dia, foi iniciado o período de coleta de dados;os animais passaram a receber as dietas líquidas experimentais, isto é, sucedâneo de leite, colostro fermentado e colostro preservado por adição de formaldeído. A quantidade de leite ou colostro oferecida foi estabelecida na base de $10 \%$ do peso vivo, reajustada semanalmente conforme o peso vivo. A ração líquida foi ministrada em duas refeições diárias, às 8 ès 16 horas. Cada animal recebeu ração inicial à vontade, e feno de Kikuiu (Pennissetum clandestinum. Hochst) de boa qualidade, produzido na fazenda.

Os componentes do sucedàneo de leite comercial e ração inicial I, também comercial, eram os seguintes:

Sucedàneo de leite: leite em pó, soro em pó, sebo refinado,lecitina, amido, soja micronizada e premix, de origem comercial. 
Ração inicial: fubá de milho, farelo de mandioca, farelo de al godão, farelo de trigo, sorgo, arroz, óleo vegetal, gordura, melaço de cana, solúveis de peixe, protenose; farelos de améndoim, girassol e linhaça; lex protéico, leveduras, farinhas de carne, peixe,pe nas e sangue, alfafa, farelos de arroz, babaçu, cevada e tomate,ger mem de milho, Refinazil, cascas de arroz, amendoim e algodão, farinha de ossos, calcário, caulim, farinha de ostras, fosfato bicálcico, e premix.

As composições químicas do sucedâneo de leite, da ra ção inicial I, do feno, encontram-se na Tabela l. As anālises foram conduzidas no laboratório do Departamento de Zootecnia da Escola Superior de Agricultura "Luiz de Queiroz", sobre amostras compostas de cada partida, segundo os métodos descritos pelo A.O.A.C. (1970).

Tabela 1 - Composição química de sucedâneo, ração inicial I e feno.

\begin{tabular}{lccc}
\hline \multirow{2}{*}{ COMPONENTES } & \multicolumn{3}{c}{ TEOR EM 100\% de M.S. } \\
\cline { 2 - 4 } & $\begin{array}{c}\text { Sucedāneo } \\
(\%)\end{array}$ & $\begin{array}{c}\text { Ração inicial } \\
(\%)\end{array}$ & $\begin{array}{c}\text { Feno } \\
(\%)\end{array}$ \\
\hline Umidade & 5 & 12 & 13,50 \\
Proteína bruta & 24 & 18 & 19,8 \\
Extrato etéreo & 17 & 2 & 3,79 \\
Fibra bruta & 1 & 7 & 20,43 \\
Matéria mineral & 8 & 8 & 11,42 \\
Ca & 1,3 & 1,3 & 0,27 \\
Fósforo & 1,1 & 0,6 & 0,18 \\
\hline
\end{tabular}


o colostro fermentado e preservado por formaldeído foi diluído com água morna na proporção de 3:llpartes colostro : par te água). O sucedâneo de leite foi reconstituído conforme recomenda ções do fabricante, isto é, l kg de sucedāneo em pó em 8 litros de àgua morna.

Os bezerros ficaram na baia individual até a desmama, que ocorreu a 35 dias de idade, cortando-se subitamente a dieta líquida. Nessa ocasião o consumo médio diário de ração inicial foi de 820 g. A quantidade de ração oferecida era reajustada semanalmente, com base na determinação do peso vivo.

A fim de controlar o consumo individual semanal de ração inicial, cada bezerro recebia ração de um determinado saco, que era pesado semanalmente, e a diferença com o peso anterior era registrada como o consumo semanal. Não houve sobra. No final do expediente, todos os cochos eram revistados e acrescentado mais alimento, se necessário, para garantir o consumo durante a noite.

Após a desmama, os bezerros eram reagrupados, criados até os 6 meses de idade, para serem avaliados os efeitos posteriores dos diferentes tratamentos recebidos durante a fase de aleitamento. No período da 6. à 14. semana, os animais eram criados em regime de pasto e feno (P. clandestinum) e ração inicial I, cujo con sumo diário máximo foi limitado a 2 quilogramas. A partir da 15. se mana, passou a ser fornecida a ração inicial II, mais barata, prepa rada na fazenda. Essa ração era constituída por grãos de milho moí- 
dos, farelos de algodão e de soja. Sua composição química figura na Tabela 2.

Tabela 2 - Composição química da ração inicial II.

\begin{tabular}{lc}
\hline COMPONENTES & $\%$ \\
Matéria seca & 87,87 \\
Proteína bruta & 17,00 \\
Extrato étéreo & 3,96 \\
Fibra bruta & 8,67 \\
Cinza bruta & 4,36 \\
Extrativo não nitrogenado & 53,88 \\
Cálcio & 0,32 \\
Fósforó & 0,18 \\
\hline
\end{tabular}

Esquema geral de arraçoamento:

a) Período do $1^{8}$ ao. $3^{\circ}$ dia:

\begin{tabular}{|c|c|c|c|c|c|c|c|}
\hline \multirow{2}{*}{\multicolumn{2}{|c|}{$\begin{array}{l}\text { IDADE } \\
\text { (dias) }\end{array}$}} & \multicolumn{6}{|c|}{ QUANTIDADE DE ALIMENTO } \\
\hline & & Colostro & SL & $\mathrm{CF}$ & CPF & RI & Feno \\
\hline & $1-3$ & $10 \% \mathrm{PV}$ & - & - & - & - & - \\
\hline & $4-14$ & - & $10 \% \mathrm{PV}$ & $10 \% \mathrm{PV}$ & $10 \% \mathrm{PV}$ & AV & AV \\
\hline & $5-21$ & - & $"$ & $"$ & $"$ & $"$ & $"$ \\
\hline & $2-28$ & - & $"$ & $"$ & $"$ & $"$ & $"$ \\
\hline & $9-35$ & - & $"$ & $"$ & $"$ & $"$ & $"$ \\
\hline $\begin{array}{l}\text { PV } \\
\text { SL } \\
C F \\
C P F \\
\text { RI } \\
\text { AV }\end{array}$ & $\begin{array}{l}=\text { Pes } \\
=\text { Suc } \\
=\text { Col } \\
=\text { Col } \\
=\text { Raç } \\
=\bar{A} V\end{array}$ & $\begin{array}{l}\text { vo; } \\
\text { eo de Leit } \\
\text { o Fermenta } \\
\text { o Preserva } \\
\text { nicial; } \\
\text { de. }\end{array}$ & $\begin{array}{l}\text {; } \\
\text { Ho com Fo } \\
\text { o col }\end{array}$ & naldeid & & & \\
\hline
\end{tabular}


b) Período do $36^{\circ}$ ao 1 bo dia:

\begin{tabular}{ccccc}
\hline \multirow{2}{*}{$\begin{array}{c}\text { Idade } \\
\text { dias })\end{array}$} & \multicolumn{4}{c}{ QUANTIDADE DE ALIMENTO. } \\
\cline { 2 - 5 } & Pasto & Feno & RI & Agua \\
\hline $36-90$ & AV & AV & $\leq 2 \mathrm{~kg} /$ dia & AV \\
$90-180$ & $n$ & $n$ & $n$ & $"$ \\
\hline
\end{tabular}

RI = Ração Inicial;

$A V=\hat{A}$ Vontade.

\section{3 - Preparo do Colostro Fermentado}

As seis primeiras ordenhas, sendo duas por dia da va ca parida, foram coletadas em latão plástico de 60 litros de capaci dade, provido de tampa. Esse recipiente foi colocado em galpão à tem peratura ambiente, para o colostro fermentar pelo menos durante sete dias antes de ser oferecido ao animal, até que a fermentação se estavilizasse. A partir do $7{ }^{\circ}$ dia até o $28^{\circ}$ dia o colostro foi fornecido aos bezerros. Nesse período,o pH. do produto manteve-se relativamente constante, indicando estabilidade dos processos fermentativos. Durante essa fase, o material foi homogeneizado duas vezes por dia, de manhã e à tarde, para se evitar a separação entre a par te sōlida (constituída principalmente de proteína e lactose) da poI ção líquida (água e gordura).

Colostros de vacas que pariram dentro de trēs dias foram misturados para evitar ou reduzir o efeito da variação indivi 
dual sobre a composição do colostro de uma vaca para outra, e ainda por economia de recipiente.

\section{4 - Preparo do Colostro Preservado com Formaldeído}

Após a ordenha, o colostro foi pesado, e quantidade de formaldeido equivalente a $1 \%$ do peso do material coletado foi ne le adicionado e misturado. Para assegurar melhor homogeneização, a mistura de formaldeído no colostro foi feita de maneira progressiva, colocando-se a quantidade total do preservativo em volumes crescentes de colostro até o total. Para as ordenhas seguintes, as mesmas operações foram observadas antes de se juntar a nova coleta à precé dente. Também o material foi homogeneizado duas vezes por dia e deixado sete dias antes de oferecido ao bezerro.

Tanto o colostro fermentado como preservado com formaldeído eram diluídos na proporção de três partes colostro para uma de água morna. Com base no peso vivo, a quantidảde diária total de colostro era estimada para cada refeição, separada em outra vasilha e diluída na quantidade adequada de água morna, pouco antes de ser fornecida aos bezerros. O fornecimento individual foi feito na proporção do peso de cada animal, em balde.

A composição química do colostro fermentado e do colostro preservado com formaldeído consta na Tabela A.l do Apêndice. 
30.

\section{5 - Preparo do Sucedâneo ou Lei te em Pó}

o leite em pó era misturado em água morna na proporção recomendada pelo fabricante, requerendo mistura enérgica e agitação para completa diluição do pó. A confecção era também executada pouco antes da hora da refeição, em quantidade suficiente para todos os bezerros.

Os animais eram descornados aos 14 dias e vacinados contra o paratifo aos 21 dias de vida. A primeira vacinação contra a febre aftosa realizou-se aos 3 meses; aos 4 meses ocorreu vacinação contra a brucelose,e contra a mangueira aos 5 meses. No final do período experimental, isto é, aos 6 meses, realizou-se a segunda vacinação contra a febre aftosa. No caso de aparecimento de diarréia, a dieta líquida era cortada pela metade, e, se não houvesse me Ihora, era feita medicação com "Oiftal" e "Hychar". A cama das baias era renovada diariamente após a limpeza com água sob pressão. Para outras ocorrências sanitárias, recorreu-se à assistência técnica do Veterinário da fazenda.

\section{6 - Delineamento Experimental}

Para avalịação estatística dos diferentes tratamentos, o delineamento foi o de "experimentos inteiramente casualizados". Foram estabelecidos três tratamentos e dez repetições, sendo cada bezerro considerado unidade experimental. Os tratamentos foram 


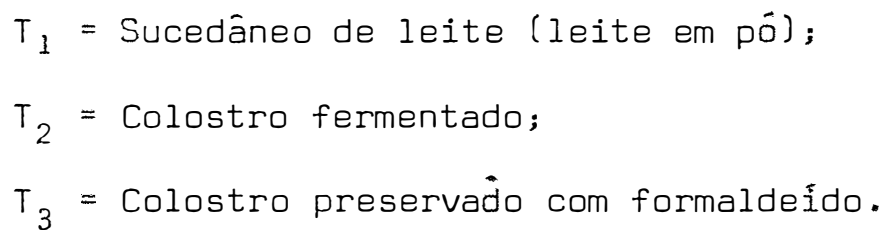

Aplicou-se o "teste de Tukey" para comparação das mé dias.

As determinações feitas para comparação dos três tra tamentos foram em relação a ganho de peso, consumo de alimento, con versão alimentar e observações sobre ocorrência de problemas sanitá rios. Os animais foram pesados ao nascer e depois semanalmente até o fim do período experimental, aos seis meses de idade, em um mesmo dia da semana, isto é, toda terça-feira, a mesma hora, antes da pri meira refeição. Os consumos de sucedâneo, de colostro e das rações iniciais, foram medidos diariamente, por animal.

Em relação a problemas sanitários, principalmente diarréia, foram registrados, em cada tratamento, o número de bezerros envolvidos e o tempo de persistência do problema.

\section{Esquema da anälise estatística}

Destacaram-se, além dos tratamentos, sexo e época de nascimento. Verificou-se se houve correlação entre peso inicial sobre consumo e ganho de peso.

O esquema de análise de variáncia adotado foi o seguinte, de acordo com COCHRAN e COX (1957). 
Causas de Variação

Tratamento

Sexo

Mès (época):

Regressão Linear

Regressão Quadrática

Regressão Cúbica

Regressão PI/C ou GP

Resíduo

PI = Peso Inicial

$C$ = Consumo;

$G P=$ Ganho de Peso.

Para as variáveis que foram significativas, foi utilizado o teste de Tukey para comparação das médias.
G.L.

2

1

3

1

1

1

1

22 


\section{1 - Aceitabilidade e Problemas Sanitärios}

As dietas de colostro fermentado e colostro preserva do por formaldeído apresentaram fácil aceitação pelos bezerros. Ape nas no primeiro dia de oferecimento, alguns bezerros não ingeriram inteiramente a quantidade oferecida. Passada esta fase, todos aceitaram espontaneamente as dietas, sem ocorréncia de sobra. Esses resultados estão de acordo com as observações de RINOSIG e BODOH (1975) e FOLEY et alii (1978) sobre as dificuldades iniciais para se fazer o bezerro ingerir quantidade sufiente de colostro fermentado e colostro preservado por formaldeído.

Em relação a problemas sanitários, o leite em pó lsu cedâneo) resultou em maior ocorréncia de diarréia, quando comparado ao colostro. Registrou-se ocorréncia de diarréia em quatro bezerros 
por trés dias, com o uso de leite em pó, e de dois bezerros durante dois dias, para cada um dos colostros. RINDSIG e BODOH (1975) tiveram 2,2 dias de distúrbios digestivos em bezerros alímentados com colostro fermentado, e 1,2 dia para o uso de colostro preservadocom formaldeído. Os resultados obtidos neste trabalho parecem melhores do que os de MULLER et alii (1976), que observaram cinco bezerros entre dez com diarréia no regime de colostro preservado com formaldeído. A maior incidência de diarréia ocasianada pela dieta de leite em pó concorda com os resultados de WHITE et alii (1974). Também DANIELS et alii (1977), trabalhando durante.336 dias com bezerros, registraram 70 dias de diarréias no tratamento de leite em pó comer cial, contra 27 dias com o uso de colostro fermentado.

4.2 - Consumo de Leite em Pó, Colostro Fermentado e Colostro Pre servado por Formaldeído

Os consumos médios semanais e diários das dietas líquidas, estão apresentados na Tabela 3. A análise de variància dos dados do consumo diário de sólidos totais figuram na Tabela 4.

As análises de variāncia dos dados de consumo semanal transformados em consumo diário, mostraram que houve efeitos sig nifícativos $(P<0,05)$ dos tratamentos sobre o consumo diário de lei te em pó, colostro fermentado e colostro preservado por formaldeído, nas fases da $1^{a} \cdot 3^{a} \cdot, 4 \stackrel{a}{\text { e }} 5^{a}$. semanas de vida. A diferença entre tra tamentos foi altamente significativa $(P<0,01)$ nos períodos da 2 ? 
e da 5! semana. Não foi observado efeito da época de nascimento sobre o consumo. O peso inicial afetou significativamente $(P<0,05)$, nos períodos da $3^{a}, 4 \stackrel{a}{!}, 5^{a}$ e e 3 ! à $5^{a}$. semanas. O efeito do peso inicial revelou-se altamente significativo $(P<0,01)$ nas fases da 1 a,

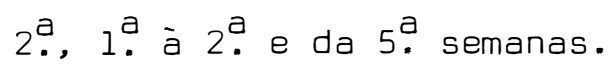

Tabela 3 - Consumos médios semanal e diário de leite em pó, colostro fermentado e colostro preservado por formaldeido ( kg de MSI.

\begin{tabular}{cccc}
\hline \multirow{2}{*}{$\begin{array}{c}\text { FASE } \\
\text { semana })\end{array}$} & Leite em Po & $\begin{array}{c}\text { TRATAMENTOS } \\
\text { Fermentado }\end{array}$ & $\begin{array}{c}\text { Colostro }+ \\
\text { Formaldeido }\end{array}$ \\
\cline { 2 - 4 } 1 & 14,8 & 14,8 & 14,8 \\
2 & 25,9 & 25,5 & 25,9 \\
3 & 27,3 & 25,5 & 26,2 \\
4 & 29,4 & 29,0 & 27,6 \\
5 & 31,5 & 30,8 & 30,1 \\
1 & 0,250 & 0,230 & 0,238 \\
2 & 0,438 & 0,397 & 0,418 \\
3 & 0,462 & 0,397 & 0,428 \\
4 & 0,497 & 0,452 & 0,447 \\
5 & 0,533 & 0,484 & 0,487 \\
$1-2$ & 0,344 & 0,313 & 0,328 \\
$3-5$ & 0,498 & 0,441 & 0,453 \\
$0-5$ & 0,436 & 0,390 & 0,403 \\
\hline
\end{tabular}




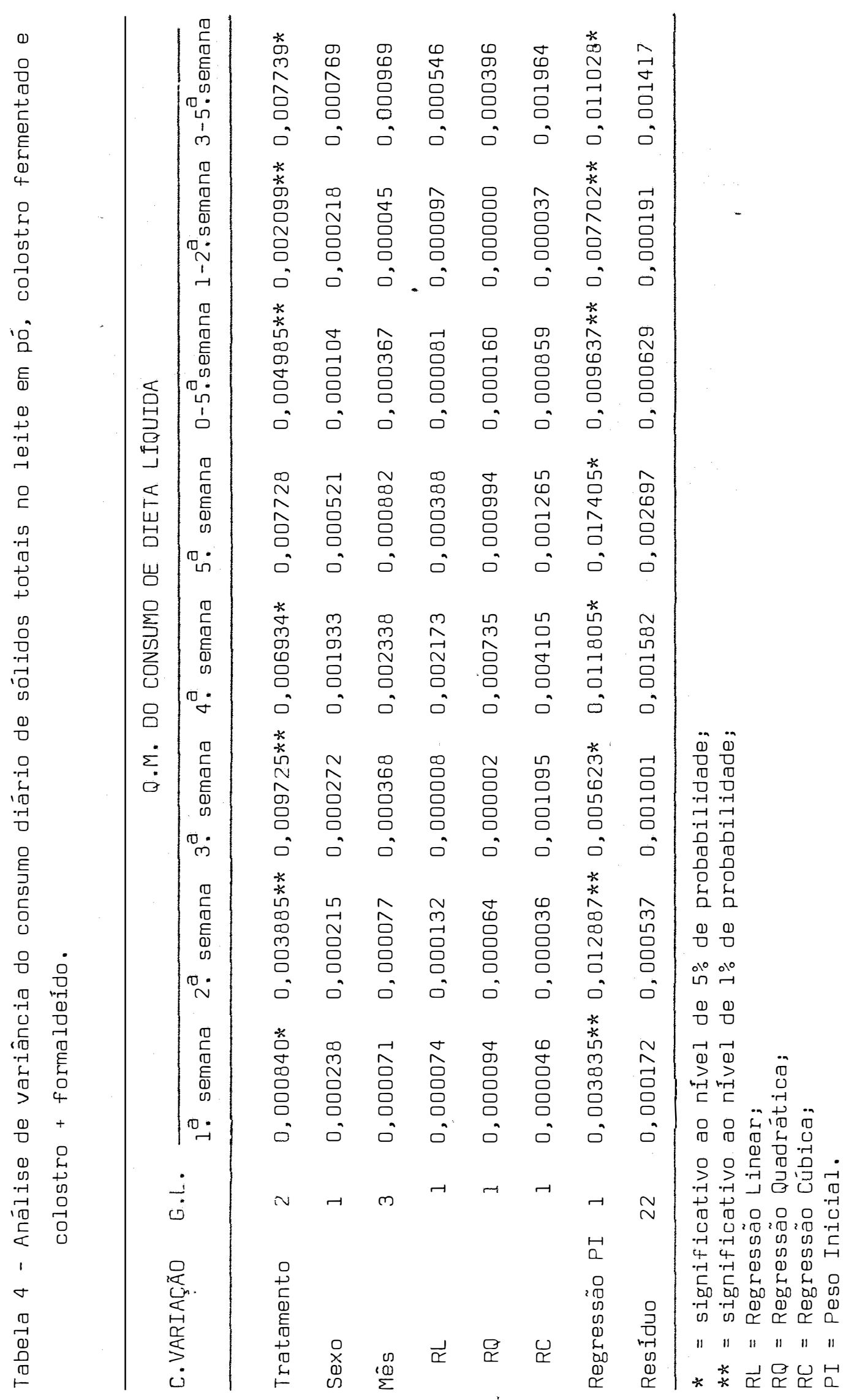


As comparações entre as médias de consumo de leite em pó, colostro fermentado e colostro preservado por formaldeído, es tão apresentadas na Tabela 5 .

Tabela 5 - Comparação entre médias diárias de consumo das dietas lí quidas (kg de sólidos totais por dia).

\begin{tabular}{ccccccccc}
\hline TRATA & \multicolumn{7}{c}{ FASES (Semanas) } \\
\cline { 2 - 8 } MENTOS & 1 & 2 & 3 & 4 & 5 & $1-2$ & $3-5$ & $0-5$ \\
\hline$T_{1}$ & $0,250 a$ & $0,439 a$ & $0,463 a$ & $0,493 a$ & $0,533 a$ & $0,344 a$ & $0,498 a$ & $0,436 a$ \\
$T_{2}$ & $0,230 b$ & $0,396 b$ & $0,394 b$ & $0,448 b$ & $0,474 a$ & $0,312 b$ & $0,439 b$ & $0,388 b$ \\
$T_{3}$ & $0,235 a$ & $0,416 a$ & $0,421 c$ & $0,445 c$ & $0,487 a$ & $0,327 c$ & $0,451 \mathrm{bc}$ & $0,401 \mathrm{bc}$
\end{tabular}

$(a, b, c)=$ Médias com letras diferentes, nas colunas, diferem entre si pelo teste de Tukey.

o leite em pó foi o alimento mais consumido em termos de matéria seca do que ambas as dietas de colostro. Na 1 a e $2^{a}$. semanas, o colostro fermentado resultou em menor ingestão de nutrientes quando comparado ao colostro preservado por formaldeído. Entretanto, na 3 ?, 4 ?, 5 ? semanas e de 0 à 5 ? semanas, não houve dife rença significativa entre o consumo médio de ambos. Nos períodos da 1. à $2^{a}$ e e 3 . à 5 ? semanas, houve maior consumo diário do colostro preservado por formaldeído em relação ao colostro fermentado.

Os bezerros alimentados com leite em pó apresentaram maior ingestão de sólidos totais do que os com colostro fermentado 
ou preservado por formaldeído, proporcionando diferença significatí va entre os tratamentos $(0,436,0,388$ e $0,401 \mathrm{~kg}$ de MS por dia) no período de 0 a 5 . semanas. Esses resultados estão déacordo com os de OANIELS et alii (1977), com consumo médio diário de 0,530 kg de leite em pó, enquanto o consumo de colostro fermentado, de 0,214 kg com desmama a 42 dias, foi muito baixo quando comparado ao deste ex perimento. Este fato pode ser divido à pouca ocorréncia de diarréia registrada na dieta de colostro fermentado, levando à ingestão completa das refeições oferecidas. O colostro preservado por formaldeí do proporcionou maior consumo de sólidos totais do que o colostro fermentado. Isto, talvez, possa ser devido a melhor preservação do colostro contra a degradação dos nutrientes. MULLER et alii (1976), desmamando bezerros aos 28 dias de vida, observaram consumo de 0,321 kg e 0,350 kg de matéria seca de colostro e de leite em pó, resulta dos semelhantes aos deste trabalho.

A anālise de variāncia indicou correlação significativa $(P<0,05)$ entre peso inicial e consumo de alimento. Isto era esperado, pois a quantidade de alimento oferecida era ajustada ao peso vivo obtido semanalmente, desde o início até o fim do experimento. Os bezerros mais pesados consumiram mais do que os mais leves. 
39.

\section{3 - Consumo de Ração Inicial}

Os resultados de consumo semanal e diário da ração inicial até final do período de aleitamento são apresentados na Tabela 6 .

Tabela 6 - Consumo de ração inicial ( $k g$ de MS).

\begin{tabular}{|c|c|c|c|}
\hline \multirow{2}{*}{$\begin{array}{c}\text { FASE } \\
\text { (Semanas) }\end{array}$} & \multicolumn{3}{|c|}{ TRATAMENTOS } \\
\hline & Leite em Pó & $\begin{array}{l}\text { Colostro } \\
\text { Fermentado }\end{array}$ & $\begin{array}{l}\text { Colostro + } \\
\text { Formaldeido }\end{array}$ \\
\hline & \multicolumn{3}{|c|}{ Consumo Semanal } \\
\hline 1. & 0,492 & 0,170 & 0,150 \\
\hline $2:$ & 1,110 & 1,330 & 1,230 \\
\hline 3 & 2,860 & 2,840 & 2,560 \\
\hline $4 \stackrel{?}{?}$ & 3,360 & 4,540 & 4,690 \\
\hline \multirow[t]{2}{*}{5} & 6,870 & 7,650 & 5,620 \\
\hline & \multicolumn{3}{|c|}{ Consumo Diário } \\
\hline $1 \stackrel{a}{.}$ & 0,058 & 0,025 & 0,049 \\
\hline $2^{a}$ & 0,124 & 0,226 & 0,192 \\
\hline $3 !$ & 0,351 & 0,367 & 0,326 \\
\hline $4 !$ & 0,502 & 0,589 & 0,583 \\
\hline $5^{a}$ & 0,868 & 0,873 & 0,603 \\
\hline $1 \stackrel{a}{\cdot}-2$ & 0,091 & 0,129 & 0,109 \\
\hline $3 \cdot-5 \stackrel{a}{.}$ & 0,574 & 0,610 & 0,504 \\
\hline - -5 . & $0,3 ن 0$ & 0,416 & 0,361 \\
\hline
\end{tabular}




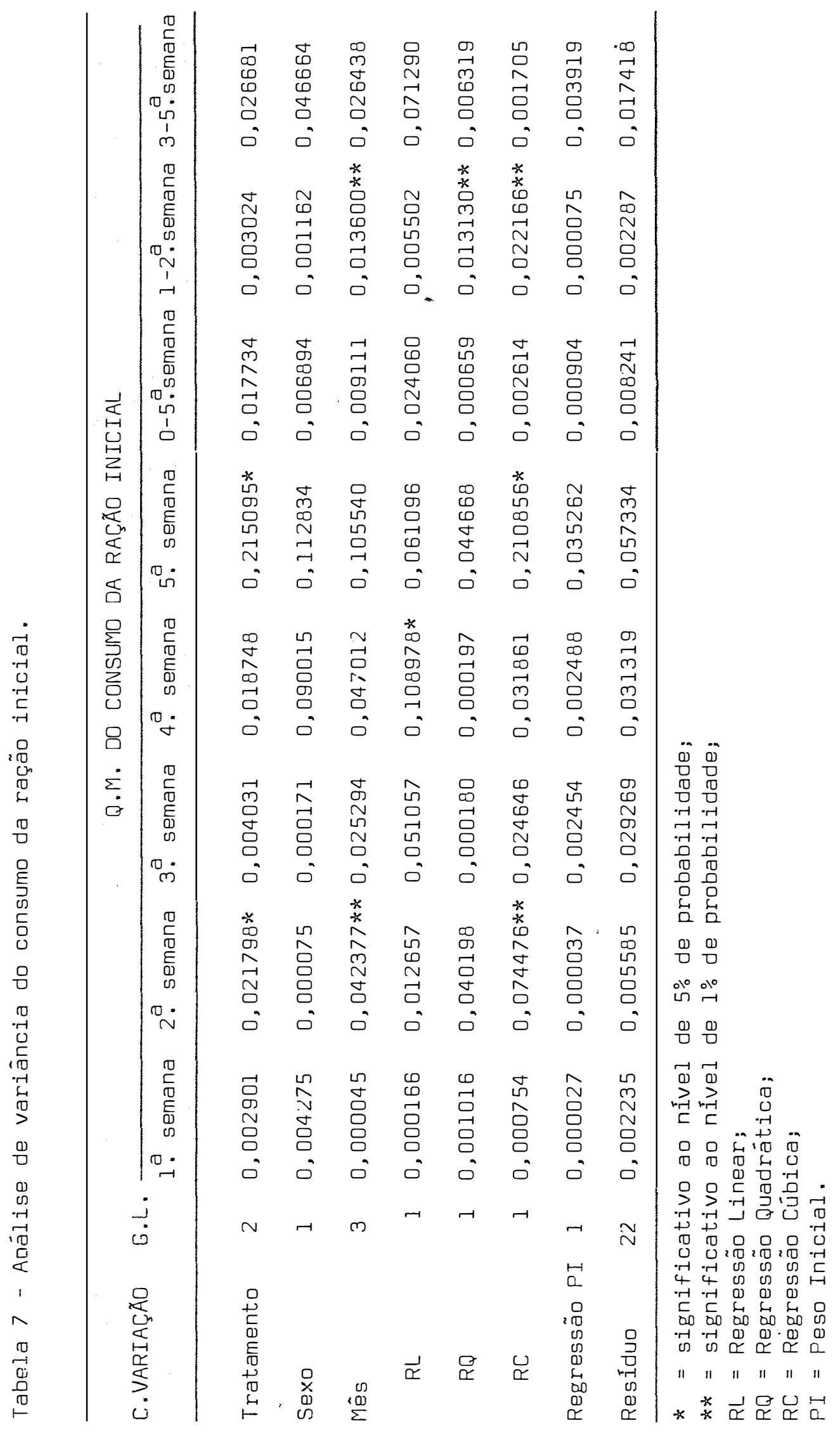

40. 
A análise de variância dos dados, apresentada na Tabela 7, mostrou que houve efeito significativo $(P<0,05)$ dos trata mentos sobre consumo de ração inicial na $2^{a}$. e 5 ? semarias. A época de nascimento influenciou significativamente $(P<0,05)$ sobre o consumo na 2 ? semana, e no período da 1 ? à 2 ? semana. Quando as somas dos quadrados relativos ao més (época) foram decompostas em seus componentes individuais de regressão linear, quadrática e cúbica, houve efeito cúbico significativo da época afetando o consumo

Na Tabela 8 aparecem as comparaçōes entre as médias diárias de consumo da ração inicial.

Tabela 8 - Comparação entre médias diárias de consumo de ração inicial durante o período de aleitamento ( $k g$ de MS).

\begin{tabular}{ccccccccc}
\hline TRATA- & \multicolumn{7}{c}{ FASES (Semanas) } \\
\cline { 2 - 9 } MENTOS & 1 & 2 & 3 & 4 & 5 & $1-2$ & $3-5$ & $0-5$ \\
\hline$T_{1}$ & $0,058 a$ & $0,124 a$ & $0,351 a$ & $0,502 a$ & $0,868 a$ & $0,091 a$ & $0,574 a$ & $0,380 a$ \\
$T_{2}$ & $0,025 a$ & $0,226 b$ & $0,367 a$ & $0,589 a$ & $0,873 a$ & $0,129 a$ & $0,610 a$ & $0,416 a$ \\
$T_{3}$ & $0,049 a$ & $0,192 b c$ & $0,326 a$ & $0,583 a$ & $0,603 b$ & $0,109 a$ & $0,504 a$ & $0,361 a$ \\
\hline
\end{tabular}

$(a, b, c)=$ médias com letras diferentes, nas colunas, diferem entre si pelo teste de Tukey.

Os bezerros alimentados com leite em pó tiveram menor consumo de ração inicial na 2 ? semana quando comparados aos cria dos com ambas as dietas de colostro. Não houve diferença significa- 
tiva entre os consumos em outras fases; entretanto, colostro fermen tado promoveu maior consumo de ração inicial em relação ao colostro preservado por formaldeído ou leite em pó. Este fató foi considerado como uma compensação à baixa ingestão de sólidos totais através da dieta líquida, sendo que o maior acréscimo no consumo de concentrado ocorreu na fase da 4 ? à 5 ? semanas de idade, quando o consumo passou de 0,589 para 0,873 kg de matéria seca por dia, enquanto, no mesmo período, os bezerros sob dieta de colostro preservado com for maldeído apresentaram a mudança de 0,583 para 0,603 kg de matéria seca por dia, conforme consta na Tabela 6. Os valores de consumo diá rio de concentrado foram superiores aos relatados por MULLER et alii (1976), JENNY et alii (1977) e RINDSIG (1976). D consumo de concentrado no período de o à 5. semanas foi de 0,416 e 0,361 kg de matéria seca por dia, enquanto esses autores relataram cerca de 0,160 a 0,200 kg de MS por dia. Não houve diferença significativa quanto ao consumo de ração inicial nas fases da 1.., 3! e 4! semanas de idade, em relação às médias dos três tratamentos. Os consumos médios diários obtidos nas fases da $1 \stackrel{a}{ }$, 2 ? e 3 ? semanas contrastaram com os registrados por RINDSIG e BODOH (1977), que foram de 0,070 MS por dia de ração inicial.

A análise de variāncia revelou-se significativa $(P<$. $<0,05\}$ para o consumo de ração inicial, nas idades de duas e cinco semanas, indicando diferenças de consumo nos diferentes tratamentos. $\mathrm{Na} 2 \dot{a}$. semana, o leite em pó, tendo sido mais consumido, teria pro- 
porcionado menor ingestão de concentrado; na 5a semana ocorreu a si tuação inversa em relação ao colostro preservado por formalideído (Ta belas 5 e 8 ).

\section{4 - Consumo Total de Alimento}

Os resultados de consumo total diário de matéria seca, obtidos somando-se os consumos de sólidos totais da dieta líqui da com a matéria seca da ração inicial, estão apresentados na Tabela 9 .

Tabela 9 - Consumo diário total de alimento durante a fase de aleitamento (kg de sólidos totais mais kg de MS da ração ini ciall.

\begin{tabular}{cccc}
\hline \multirow{2}{*}{$\begin{array}{c}\text { FASE } \\
\text { semana) }\end{array}$} & Leite em Pó & $\begin{array}{c}\text { Tolostro } \\
\text { Fermentado }\end{array}$ & $\begin{array}{c}\text { Colostro }+ \\
\text { Formaldeído }\end{array}$ \\
\cline { 2 - 4 } 1 & 0,314 & 0,251 & 0,257 \\
2 & 0,577 & 0,561 & 0,571 \\
3 & 0,817 & 0,750 & 0,742 \\
4 & 1,005 & 1,016 & 1,029 \\
5 & 1,387 & 1,420 & 1,150 \\
$3-5$ & 0,445 & 0,405 & 0,414 \\
$0-5$ & 1,070 & 1,062 & 0,974 \\
& 0,820 & 0,796 & 0,750 \\
\hline
\end{tabular}




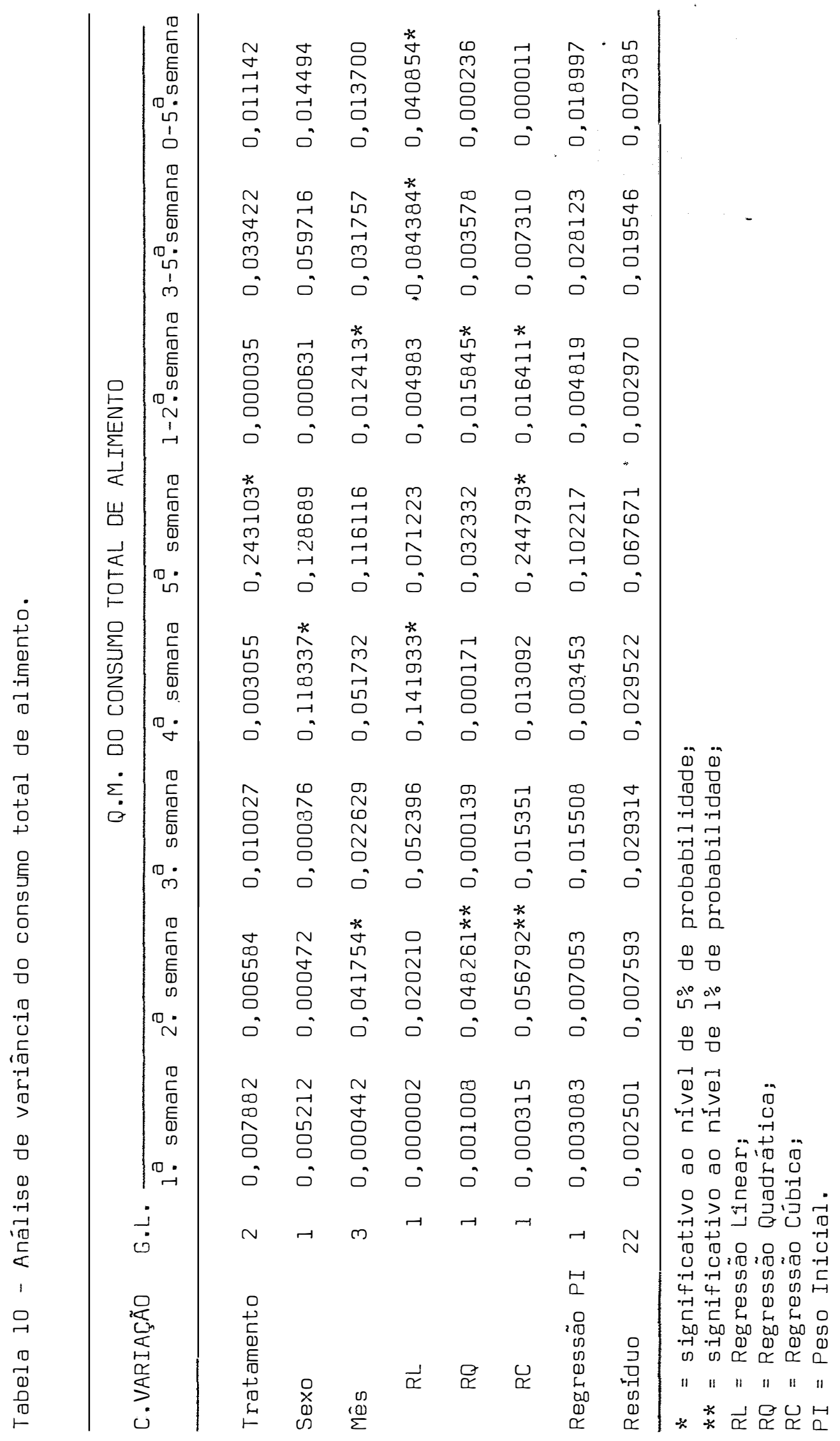


A análise de variância dos dados de consumo total,apresentada na Tabela 10, indica que houve efeito significativo dos tratamentos sobre o consumo na 5. semana. A época de-nascimento influenciou significativamente $(P<0,05)$ sobre o consumo na 2 ? semana e no período da $1^{a}$ à $2^{a}$. semanas, apresentando uma regressão quadrática e cúbica significativas $(P<0,01$ e 0,05). A regressão linear foi significativa $(P<0,05)$ nos períodos da 4 !. da 2 ? à 5 ! e de 0 à 5. semanas, com consumo diminuindo de agosto a dezembro. Hou ve também efeito significativo $(P<0,05)$ do sexo sobre o consumo total de alimento na. 4 ? semana, sendo que os animais machos consumi ram mais do que as fêmeas.

As comparações entre as médias diārias de ingestão de matéria seca durante as cinco primeiras semanas constam na Tabela 11.

Tabela 11 - Comparação entre médias diārias de consumo total de ali mento durante o período de aleitamento ( $\mathrm{kg}$ de MS por dia) .

\begin{tabular}{ccccccccc}
\hline $\begin{array}{c}\text { TRATA- } \\
\text { MENTOS }\end{array}$ & 1 & 2 & 3 & 4 & 5 & $1-2$ & $3-5$ & $0-5$ \\
\hline$T_{1}$ & $0,314 a$ & $0,577 a$ & $0,317 a$ & $1,005 a$ & $1,387 a$ & $0,445 a$ & $1,070 a$ & $0,320 a$ \\
$T_{2}$ & $0,251 a$ & $0,561 a$ & $0,750 a$ & $1,016 a$ & $1,420 a$ & $0,405 a$ & $1,062 a$ & $0,796 a$ \\
$T_{3}$ & $0,257 a$ & $0,571 a$ & $0,742 a$ & $1,150 a$ & $1,150 b$ & $0,414 a$ & $0,974 a$ & $0,750 a$
\end{tabular}

$(a, b)=$ médias com letras diferentes, nas colunas, diferem entre si pelo teste de Tukey. 
Os animais apresentaram consumo semelhante em todas as fases exceto a 5 ? semana, em que os bezerros alimentados com co lostro fermentado tiveram consumo maior do que os crïjos sob regime de colostro preservado por formaldeído.

O consumo total de alimento (kg de MS por dia da die ta líquida mais kg de MS da ração inicial por dial apresentou diferença significativa $(P<0,05)$ somente na 5 a semana, conforme a aná lise da variància. Os consumos médios para os três tratamentos foram respectivamente $1,420,1,347$ e 1,150 kg de MS por dia, contrastando com 0,52 e 0,50 kg de MS por dia registrados por MULLER et alii (1976) para o colostro fermentado e colostro preservado por formaldeído. RINDSIG e BODOH (1977), desmamando bezerrós com cinco semanas de idade, relataram consumo médio total de 0,56 de MS por dia para ambos os métodos de aproveitamento de colostro. Estas dife renças podem ser devidas às proporções de diluição de colostro que foram de três partes de colostro para uma de água morna contra duas para uma utilizada pelos primeiros autores. Os resultados foram superiores aos de DANIELS et alii (1977), que anotaram o consumo diário de 0,785 e 0,752 kg de MS para o leite em pó e colostro fermentado, e, mesmo assim, com a desmama praticada a 42 dias de idade, e o colostro diluído por partes iguais. Deve-se ressaltar que a diluição 3:1 proporciona maior ingestão de matéria seca se comparado às diluições 2:1 e 1:1. 
Comparando os dados obtidos com as informações de re querimentos nutricionais constantes nas normas do NRC (National Research Council), ano 1978, para animais de 5 semanas, de raça pesada como a Holandesa, verifiçou-se que o consumo foi dentro do estimado, pois os animais consumiram 1,420, 1,347 e 1,150 kg de MS por dia, e, segundo as normas, o consumo deveria ser de $1,31 \mathrm{~kg}$ de MS por dia.

\section{5 - Ganho de Peso}

Os ganhos médios diários e a evolução do peso vivo dos animais durante todo o período experimental podem ser observados nas Tabelas 12 e 13.

A análise de variāncia do ganho de peso, apresentada na Tabela 14, indica que houve efeito signifiçativo $(P<0,01)$ dos tratamentos sobre ganho de peso nas $2^{a}$ e $26^{\text {a }}$ semanas, e nos períodos da 6. à 26! semanas $(P<0,05)$, e de 0 à $26^{a}$. semanas $(P<0,05)$. 0 peso inicial afetou significativamente o ganho de peso $(P<0,05)$ somente no período da 1 . à 2 ! semanas. Sexo também afetou o desempe nho dos animais $(P<0,05)$ na 3 ! semana, as fêmeas ganhando mais peso do que os machos. 
Tabela 12 - Ganho médio diário de peso vivo (kg).

\begin{tabular}{cccc}
\hline \multirow{2}{*}{$\begin{array}{c}\text { FASES } \\
\text { (semanas) }\end{array}$} & Teite em Pó & $\begin{array}{c}\text { Colostro } \\
\text { Fermentado }\end{array}$ & $\begin{array}{c}\text { Colostro }+ \\
\text { Formaldeido }\end{array}$ \\
\cline { 2 - 4 } 1 & $-0,141$ & $-0,142$ & 0,000 \\
2 & 0,071 & 0,168 & $-0,112$ \\
3 & 0,459 & 0,589 & 0,369 \\
4 & 0,548 & 0,781 & 0,569 \\
5 & 0,458 & 0,609 & 0,602 \\
$1-2$ & $-0,041$ & 0,004 & $-0,060$ \\
$3-5$ & 0,489 & 0,660 & 0,513 \\
$0-5$ & 0,281 & 0,396 & 0,284 \\
$0-12$ & 0,393 & 0,395 & 0,367 \\
26 & 0,614 & 0,999 & 0,700 \\
$6-26$ & 0,665 & 0,605 & 0,533 \\
$0-26$ & 0,591 & 0,577 & 0,485 \\
\hline
\end{tabular}


Tabela 13 - Evolução do peso vivo dos bezerros (kg).

\begin{tabular}{|c|c|c|c|}
\hline \multirow{2}{*}{$\begin{array}{c}\text { IDADE } \\
\text { (Semanas) }\end{array}$} & \multicolumn{3}{|c|}{ TRATAMENTOS } \\
\hline & $T_{1}$ & $\mathrm{~T}_{2}$ & $\mathrm{~T}_{3}$ \\
\hline 1 & 37,9 & 37,9 & 38,1 \\
\hline 2 & 37,0 & 36,9 & 38,1 \\
\hline 3 & 37,5 & 38,0 & 37,4 \\
\hline 4 & 40,7 & 42,2 & 39,9 \\
\hline 5 & 44,6 & 47,6 & 43,9 \\
\hline 6 & 47,8 & 51,8 & 48,1 \\
\hline 7 & 51,6 & 53,9 & 51,2 \\
\hline 8 & 55,1 & 57,7 & 55,6 \\
\hline 9 & 57,2 & 61,9 & 56,8 \\
\hline 10 & 63,8 & 63,7 & 61,8 \\
\hline 11 & 66,6 & 68,0 & 66,2 \\
\hline 12 & 70,8 & 72,1 & 69,1 \\
\hline 13 & 72,8 & 76,9 & 70,9 \\
\hline 14 & 78,8 & 81,2 & 75,2 \\
\hline 15 & 81,7 & 87,0 & 82,4 \\
\hline 16 & 89,6 & 93,7 & 87,3 \\
\hline 17 & 93,7 & 97,1 & 91,2 \\
\hline 18 & 98,4 & 105,1 & 94,6 \\
\hline 19 & 104,4 & 110,7 & 99,8 \\
\hline 20 & 110,7 & 115,8 & 103,1 \\
\hline 21 & 118,8 & 119,7 & 109,9 \\
\hline 22 & 124,7 & 121,6 & 114,3 \\
\hline 23 & 130,9 & 128,7 & 117,7 \\
\hline 24 & 139,2 & 133,7 & 122,6 \\
\hline 25 & 139,9 & 137,9 & 126,0 \\
\hline 26 & 147,7 & 143,1 & 127,5 \\
\hline
\end{tabular}


50.

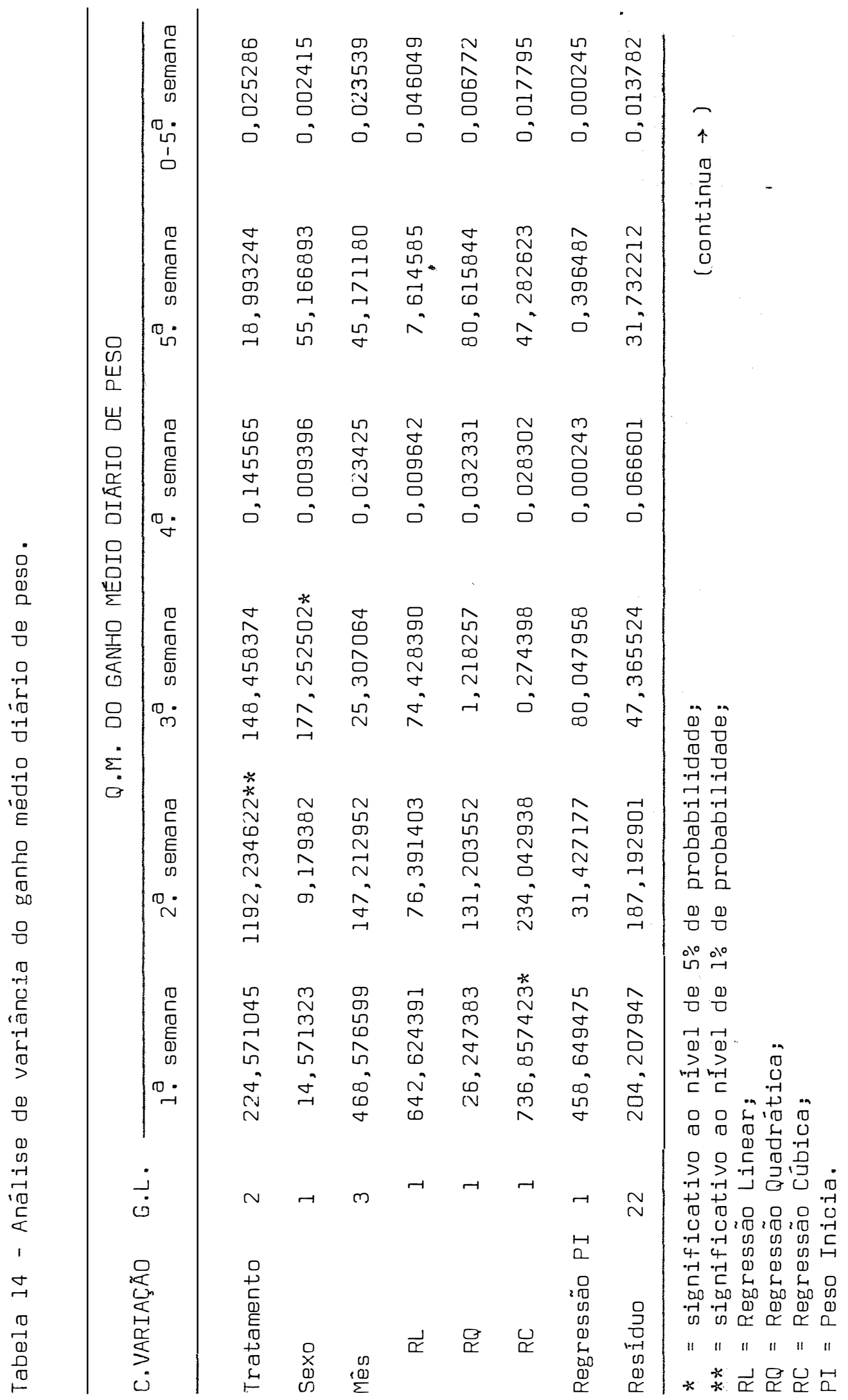


51.

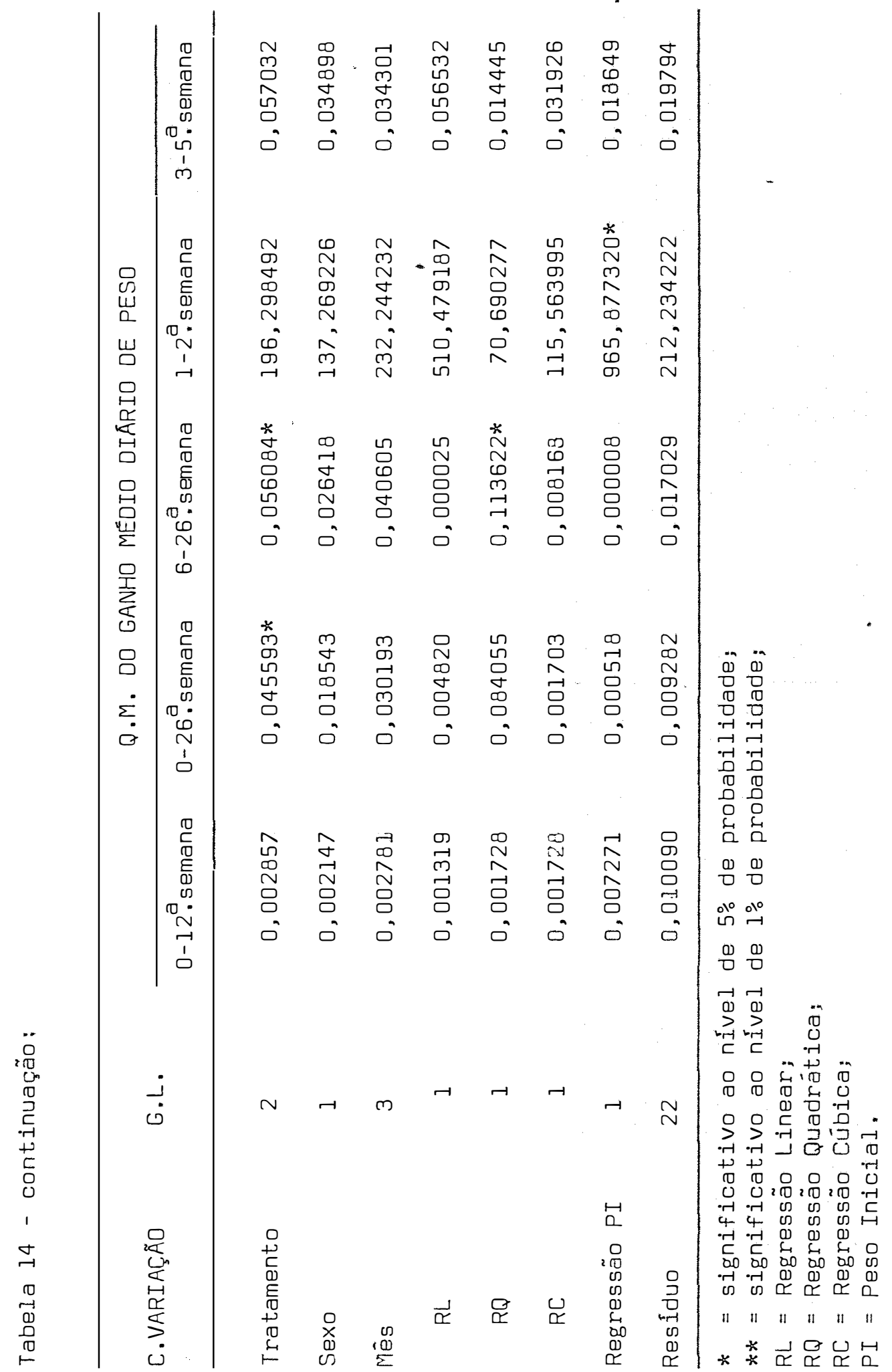


52.

Tabela 15 - Comparação entre médias de ganho diário de peso (kg de peso vivo por dial.

\begin{tabular}{cccc}
\hline FASES & \multicolumn{3}{c}{ TRATAMENTOS } \\
\cline { 2 - 4 } (Semanas) & Leite em Pó & $\begin{array}{c}\text { Colostro } \\
\text { Fermentado }\end{array}$ & $\begin{array}{c}\text { Colostro }+ \\
\text { Formaldeido }\end{array}$ \\
\hline 1 & $-0,141 a$ & $-0,142 a$ & $0,000 a$ \\
2 & $0,071 a$ & $0,168 \mathrm{~b}$ & $-0,112 \mathrm{c}$ \\
3 & $0,459 a$ & $0,589 a$ & $0,365 a$ \\
4 & $0,548 a$ & $0,781 a$ & $0,569 a$ \\
5 & $0,458 a$ & $0,609 a$ & $0,602 a$ \\
$1-2$ & $-0,041 a$ & $0,004 a$ & $-0,060 a$ \\
$0-5$ & $0,489 a$ & $0,660 a$ & $0,513 a$ \\
$0-12$ & $0,281 a$ & $0,396 a$ & $0,284 a$ \\
26 & $0,393 a$ & $0,395 a$ & $0,367 a$ \\
$6-26$ & $0,614 a$ & $0,999 b$ & $0,700 a$ \\
$0-26$ & $0,665 a$ & $0,605 a$ & $0,533 a$ \\
\hline
\end{tabular}

$(a, b, c)=$ Médias com letras diferentes, nas linhas, diferem entre si pelo teste de Tukey. 
53.

Observando-se o desempenho dos bezerros nos três trä tamentos até a desmama, nota-se que houve vantagem do colostro fermentado sobre os outros sistemas de aleitamento, apesar das diferen ças não terem sido significativas $(\rho>0,05)$, com exceção na $2^{a}$ ? e 26. semanas. A diferença significativa $(P<0,05)$ no ganho de peso na $2^{a}$. semana pode ser explicada pela ocorrência de diarréia, que ocasionou perda de peso dos bezerros alimentados por colostro preser vado por formaldeído; quanto ao alto ganho de peso observado na 26 ? semana, nos bezerros que receberam colostro fermentado, parece não haver explicação deste fato, pois todos os animais após desmama eram criados nas mesmas condições alimentares e sanitárias.

Os ganhos diários de peso de 0,281, 0,396 e 0,284 kg para os respectivos tratamentos, estão de acordo com os de MULLER (1976), DANIELS et alii (1977), YUYU et alii (1976), RINDSIG e BODOH (1977), que reportaram ganho diário de 0,237 a 0,350 kg no período de 0 à 5a semana. Entretanto, JENNY et alii (1977), alimentando bezerro com colostro fermentado, observaram ganho diário médio de $0,460 \mathrm{~kg}$ de peso vivo, no período de 0 à 4 ? semana. Por outro lado, RINDSIG (1976) observou ganho diário de peso inferior $(0,210 \mathrm{~kg})$ ao registrado neste experimento, alimentando bezerros com colostro fermentado diluído na proporção de $3: 1$, enquanto OTTERBY et alii (1976) reportaram ganho de peso diário de 0,188 kg e 0,225 kg para bezerros alimentados com leite em pó e colostro fermentado, sendo a desmama aos 28 dias de idade. 


\section{6 - Conversão Al imentar}

As conversões alimentares, nos diferentes tratamentos, constam na Tabela 16, e a correspondente análise de variāncia na Tabela 17.

Tabela 16 - Conversão alimentar dos bezerros na fase de 0 a 5 ? semana de idade.

\begin{tabular}{cccc}
\hline \multirow{2}{*}{$\begin{array}{c}\text { Número do } \\
\text { Bezerro }\end{array}$} & Leite em Pó & $\begin{array}{c}\text { Colostro } \\
\text { Fermentado }\end{array}$ & $\begin{array}{r}\text { Colostro + } \\
\text { Formaldeido }\end{array}$ \\
\cline { 2 - 4 } 1 & 2,63 & 1,42 & 1,65 \\
2 & 3,42 & 2,00 & 2,58 \\
3 & 1,97 & 1,37 & 1,77 \\
4 & 6,13 & 4,65 & 2,59 \\
5 & 3,73 & 1,68 & 5,92 \\
6 & 3,96 & 2,28 & 2,53 \\
7 & 2,59 & 2,55 & 5,10 \\
8 & 2,12 & 1,65 & 3,68 \\
9 & 2,51 & 2,32 & 2,47 \\
10 & 3,68 & 2,38 & 3,03 \\
\hline Média & 3,27 & 2,23 & 3,13 \\
\hline
\end{tabular}


Tabela 17 - Análise de variância das conversões alimentares no período de 0 à 5 a semana de aleitamento.

\begin{tabular}{|c|c|c|}
\hline Causas da Variação & G.L. & Q.M. \\
\hline Tratamentos & 2 & 1,129896 \\
\hline Sexos & 1 & 0,057620 \\
\hline Mês & 3 & 3,063736 \\
\hline$R L$ & 1 & 0,334183 \\
\hline$R Q$ & 1 & 0,945545 \\
\hline $\mathrm{RC}$ & 1 & $7,911410 *$ \\
\hline Regressão PI & 1 & 0,217268 \\
\hline Resíduo & 22 & 1,341526 \\
\hline
\end{tabular}

* = Significativo ao nível de 5\% de probabilidade.

Não houve efeito significativo dos tratamentos, do sexo, da época de nascimento e do peso inicial sobre a conversão alimentar dos animais. O efeito significativo da regressão cúbicacon firma que o aproveitamento das dietas pelos bezerros não está rela cionado com a época do ano.

Os resultados obtidos $(3,27,2,23$ e 3,13) estão de acorda com os reportados por YUYU et alii (1976), de 2,89 e 2,92, em regime de leite em pó e colostro fermentado.

Por outro lado, MULLER et alii (1976), desmamando be zerros com 28 dias de idade, observaram conversões alimentares de 
56.

4,52 e 4,39 para animais alimentados com colostro fermentado, indicando utilização inferior das dietas de colostro fermentado ou preservado por formaldeĩdo. 


\section{CONCLUSÕES}

O uso de colostro nas formas fermentado ou preservado por formaldeído, apesar das dificuldades em fazer o bezerro inge rir quantidade suficiente de nutrientes no primeiro dia de oferecimento, constitui excelente processo prático de conservação da sobra de colostro para aproveitamento na fase de aleitamento do bezerro.

$$
\text { Uma vez que o colostro fermentado ou preservado por }
$$
formaldeído promove consumo de matéria seca suficiente para ganhos de peso normais e acima daqueles constantes nas Normas de Alimentação, pode-se considerar este alimento excelente substituto do leite integral ou de sucedāneos usualmente utilizados na alịmentação de bezerros.

Em relação a melhor forma de conservação, a fermenta ção à temperatura ambiente parece levar vantagem sobre o uso de adi tivo, tanto pela maior facilidade de preparo do alimento, quanto pe lo melhor valor nutritivo. 
58.

\section{LITERATURA CITADA}

ASSOCIATION OF OFF́ICIAL AGRICULTURAL CHEMISTS, 1970. Officiam Methods of Analysis. $11^{\text {th }}$ Edition. Washington, O.C.

CHIK, A.B.; A.S. ACHACOSO; D.E. EVANS E L.L. RUSOFF, 1975. Growth and feed efficiency of young calves fed milk replacer "waste" milk, or fermented colostrum. J. Dairy Sci. 58: 742 (Abstr.).

COCHRAN, W.G. e G.M. COX, 1957. Experimental Design. John Wiley \& Sons, Nova York, Chapman \& Hall, Londres. 611 p.

OANIELS, L.V. e R. HALL, 1975. Feeding direct acified cultured and naturally fermented colostrum to dairy calves. J. Dairy Sci. 58: 743 (Abstr.).

- DANIELS, L.B.; J.R. HALL; Q.R. HORNSBY e J.A. COLLIN, 1977. Feeding naturally fermented, cultured, and direct acidified colostrum to dairy calves. J. Dairy Sci. 60: 992. 
FOLEY, J.A. e D.E. OTTERBY, 1978. Availability storage, treatment, composition, and feeding value of surplus colostrum: A Review. J. Dairy Sci. 61: 103:3.

FOLEY, J.A. E D.E. OTTERBY, 1979. Performance of calves fed colostrum stored by Freezing, fermentation, or treatment with lactic or adipic acid. J. Dairy Sci. 62: 459.

GONZALEZ, F.; F. GARCIA e M.T. LEON, 1978. Colostro: uso em alimen tación de terneros bajo un sistema de destete temprano. Ciência. e Investigación Agrária $\underline{5}$ (1/2): 65.

JACOBSON, W.C.; H.T. CONVERSE; H.G. WISEMAN E L.A. MOORE, 1951. The effect of substituiting colostrum for whole milk in the ration of dairy calves. J. Dairy Sci. 34: 905.

JENNY, B.F.; S.E. MILLS e G.D. O'DELL, 1977. Diluition rates of sour colostrum for dairy calves. J. Dairy Sci. 60: 942.

KAESER, H.E. e T.S. SUTTON, 1948. Beneficial effect and economic importance of using all colostrum produced in calf raising. J. Dairy Sci. 31: 523 .

KAISER, A.G., 1977. The use of colostrum preserved with formalin for rearing calves. Austr. J. Exp. Agric. Anim. Husb. 17: 221.

MORRIL, J.L.; R. MICKELSEN e A.D. DAYTON, 1974. Sour colostrum, cuI tured milk, and antibiotic for young calves. J. Dairy Sci. 57: 643 (Abstr.). 
MULLER, L.D.; F.C. LUDENS e J.A. RDDK, 1976. Performance of calves fed fermented colostrum or colostrum with aditives during warm ambient temperatures. J. Dairy Sci. 59: 930.

NATIONAL RESEARCH COUNCIL, 1978. Nutrient Requirements of Domestic. Animals, $n^{8}$ 3. Nutrient Requirements of Dairy Cattle. National Research Council, Washington, D.C.

- OtTerby, D.E.; D.G. JOHNSON e H.W. POLZIN, 1976. Fermented colostrum or milk replacer for growing calves. J. Dairy Sci. 59: 2001.

PLOG, J.; J.T. HUBER e W. OXENOER, 1974. Growth, dearrhea, and gamma globulin of calves fed frozen and fermented colostrum. J. Dairy Sci. 57: 642 (Abstr.).

POLZIN, H.W.; D.E. OTTERBY e G.D. MARX, 1975. Effects of diluition and abrupt changes in diet on calves fed fermented colostrum. J. Dairy Sci. 58: 744 (Abstr.).

* POLZIN, H.W.; D.E. OTTERBY e O.G. JOHNSON, 1977. Responses of calves fed fermented or acidified colostrum. J. Dairy Sci. 60: 224.

RINDSIG, R.B., 1975. Evaluation of fermented colostrum fed at $1: 1$, 2:1, 3:1 diluitions compared to whole milk. J. Dairy Sci. 58: 743 (Abstr.).

$\therefore$ RINDSIG, R.B. e G.W. BODOH, 1977. Growth of calves fed colostrum naturally fermented, or preserved with propionic acid or formaldehyde. J. Dairy Sci. 60: 79. 
Van den BROEK, G. e P.R. SHELLENBERGER, 1975. Fermented colostrum as a replacement for whole milk in the diet of dairy calves. J. Dairy Sci. 58: 743 (Abstr.).

WHITE, R.W.; D.H. YUNGBLUT; J.L. ALBRIGHT; B.W. CROWL E F.J. BABEL, 1974. Composition and nutritive value of fermented colostrum for feeding dairy calves. J. Dairy Sci. 57: 643.

WINTER, K.A., 1976. A feeding program for dairy calves weaned at 3 weeks of age. Can. J. Anim. Sci. 56: 840 (Abstr.).

WINTER, K.A., 1978. Response to weaning at two to five weeks of age the young dairy calf. Can. J. Anim. Sci. 58: 377. 
62.

A P E N D I C E

Tabela A.l - Composição química do colostro fermentado e preservado por formaldeído.

\begin{tabular}{lcc}
\hline COMPONENTES & $\begin{array}{c}\text { Colostro } \\
\text { Fermentado }\end{array}$ & $\begin{array}{c}\text { Colostro }+ \\
\text { Formaldeído }\end{array}$ \\
\hline pH & 4,54 & 4,57 \\
Sólidos totais & 14,55 & 15,12 \\
Proteína bruta & 5,6 & 5,8 \\
N.N.P. & 0,9 & 0,7 \\
Gordura & 4,20 & 4,50 \\
Cinza & 0,85 & 0,90 \\
\hline
\end{tabular}

